\title{
PENGARUH PENDAMPINGAN PEMBERIAN ASI TERHADAP SEKRETORI IMUNOGLOBULIN A (sIg A) PADA NEONATUS DI WILAYAH KERJA PUSKESMAS RUMBAI PEKANBARU 2017
}

\author{
Isrowiyatun Daiyah, Hj. Juraida Roito Hrp \\ *Jurusan Kebidanan Poltekkes Kemenkes Riau
}

\begin{abstract}
ABSTRAK
Pemberian air susu ibu (ASI) merupakan salah satu strategi utama untuk memenuhi kecukupan gizi, mencegah penyakit dan kematian. Salah satu kandungan dari ASI adalah kolostrum yang sangat berguna bagi bayi dimana terkandung zat kekebalan terutama sekretori immunoglobulin A ( $\operatorname{Sg} \mathrm{A}$ ) untuk melindungi bayi dari berbagai penyakit infeksi seperti diare. Tujuan penelitian ini untuk mengetahui pengaruh pendamping pemberian ASI terhadap kadar sekretori imunoglobulin A (sIg A) pada neonatus di Wilayah Kerja Puskesmas Rumbai Pekanbaru 2017.

Desain penelitian adalah quasy eksperiment dengan pendekatan Pretest dan Posttest Control Group. Sampel pada penelitian ini dilakukan pada 15 orang neonatus untuk kelompok yang diberikan pendampingan pemberian ASI dan 15 orang neonatus yang tidak dilakukan pendampingan pemberian ASI di wilayah kerja Puskesmas Rumbai Pekanbaru, Mei - Oktober 2017. Sampel dipilih berdasarkan Consecutive Sampling. Pemeriksaan kadar sIgA dilakukan dilaboratorium Biomedik Fakultas Kedokteran Unand dengan Metode Enzyme Linked Immunosorbent Assay (ELISA) Capture Test. Uji normalitas data dengan Shapiro-Wilk, uji perbedaan kadar Sekretori Imunoglobulin A (sIg A) pada neoonatus yang dilakukan pendampingan pemberian ASI dengan yang tidak dilakukan pendampingan pemberian ASI, menggunakan uji T Independen.

Hasil uji statistik menunjukkan ada perbedaan yang signifikan rata-rata atau mean kadar sIg A neonatus sebelum (hari ke-1) dan setelah (hari ke-28) tidak dilakukan pendampingan dan dilakukan pendampingan pemberian ASI $(p=0,000) ;(p=0,004)$, kemudian tidak ada perbedaan yang signifikan antara kadar sIg A dari neonatus yang dilakukan pendampingan pemberian ASI dibandingkan dengan neonatus yang tidak dilakukan pendampingan pemberian ASI ( $\mathrm{p}=0.625)$.

Kesimpulan penelitian ini adalah pendampingan pemberian ASI akan berpengaruh terhadap peningkatan kadar sIg A sehingga disarankan bagi para bidan dapat memberikan pendidikan kesehatan kepada masyarakat khususnya ibu menyusui agar memberikan ASI ekslusif serta tetap melakukan pendampingan pemberian ASI pada ibu menyusui, terutama pendampingan dari keluarga.

Kata kunci : Sekretori Imunoglobulin A (sIg A), Neonatus, Pendampingan Pemberian ASI
\end{abstract}




\section{PENDAHULUAN}

Kekurangan gizi masih merupakan salah satu isu sentral yang melatarbelakangi kematian anak yang disebabkan oleh penyakit infeksi. Pemberian air susu ibu (ASI) merupakan salah satu strategi utama untuk memenuhi kecukupan gizi, mencegah penyakit dan kematian akibat penyakit infeksi (diare) padaawal kehidupan bayi. Hal ini berhubungan dengan kandungan nutrisi ASI termasuk, adanya faktor imunitas pada ASI baik imunitas nonspesifik maupun imunitas spesifik (adaptif) (Morrow \& Rangel, 2004).

Air susu ibu merupakan makanan terbaik untuk bayi pada awal kehidupan. World Health Organization (WHO) tahun 2012, merekomendasikan sebaiknya bayi diberikan ASI selama paling sedikit 6 bulan dan makanan padat seharusnya diberikan sesudah bayi berumur 6 bulan dan pemberian ASI dilanjutkan sampai anak berumur dua tahun. Cakupan ASI eksklusif di Negara Amerika tahun 2012yaitu hanya 32,1\% pada 6 bulan pertama kelahiran (Heymann, et al., 2012; WHO and UNICEF, 2012).

Pemberian ASI mempunyai dampak positif baik bagi ibu maupun bagi bayi, bagi bayi menyusui mempunyai peran penting untuk pertumbuhan, perkembangan, kesehatan dan kelangsungan hidup bayi, karena ASI kaya dengan zat gizi makronutrien dan mikronutrien. Bagi ibu, menyusui dapat mengurangi risiko perdarahan postpartum, involusi uteri lebih cepat karena peningkatan kadar oksitosin, menjarangkan kehamilan yang disebabkan karena terjadinya amenore laktasi, mengurangi risiko kanker payudara dan kanker ovarium, lebih ekonomis dan praktis (WHO, 2002; American Academy of Pediatrics, 2005; Ballard and Morrow, 2013).

Cakupan ASI eksklusif di Indonesia pada tahun 2010 adalah 33,6\%, meningkat menjadi $38,5 \%$ pada tahun
2011 dan 42\% pada tahun 2012 serta mengalami penurunan pada tahun 2013 menjadi 30,2\% dan tahun 2015 mengalami peningkat sebesar 55,7\%.Rendahnya cakupan ASI eksklusif secara Nasional tentu perlu mendapat perhatian lebih dari pemerintah. Penggalakan ASI memang bukan hal yang baru namun berbagai upaya untuk meningkatkannya terus dilakukan baik oleh pemerintah maupun swasta dan juga masyarakat peduli ASI, karena hasil cakupan ASI eksklusif belum mencapai target yang diinginkan secara Nasional yaitu sebanyak $80 \%$. Hal ini terjadi karena rendahnya pencapaian program ASI eksklusif pada setiap Provinsi dan wilayah Kabupaten dan Kota di Indonesia (SDKI, 2012; Kementerian Kesehatan Republik Indonesia, 2013 dan 2015; Riset Kesehatan Dasar, 2013).

Cakupan pemberian ASI eksklusif di Provinsi Riau yaitu di Kota Pekanbaru pada tahun 2014 mencapai 52,4\%, sedangkan pada tahun 2015 mengalami peningkatan sebesar $68,8 \%$. Pencapaian ini masih jauh di bawah target Nasional sebesar 80\% di tahun 2015 (Dinas Kesehatan Kota Pekanbaru).

Bayi yang diberikan ASI eksklusif akan lebih sehat dan lebih jarang sakit dibandingkan dengan bayi yang tidak mendapat ASI eksklusif karena di dalam ASI terdapat kolostrum yang berfungsi sebagai zat kekebalan, kolostrum ini akan melindungi bayi dari berbagai penyakit termasuk penyakit diare. Kolostrum pada ASI sangat berguna bagi bayi dimana terkandung zat kekebalan terutama immunoglobulin A $(\operatorname{Ig} \mathrm{A})$ untuk melindungi bayi dari berbagai penyakit infeksi seperti diare (Hidayat, 2012).

Di negara berkembang ASI sangat berperan dalam mencegah terjadinya infeksi maupun penyakit diare. Berdasarkan laporan WHO pada tahun 2002, tingkat mortalitas akibat penyakit infeksi menurun secara mencolok pada bayi yang mendapat ASIdibandingkan dengan yang mendapat susu formula. 
Beberapa dari hasil penelitian sebelumnya menunjukkan bahwa ASI dapat berfungsi sebagai pembawa kekebalan pasif pada saluran cerna bayi sementara sistem imun lokal maupun sistemik pada bayi masih imatur. Selain itu ASI dapat beradaptasi dengan baik dan tetap utuh hingga tiba di usus halus bayi. Kandungan protein ASI memiliki berbagai aktivitas biologis diantaranya sebagai antimikrobial, imunomodulator dan terdapat asam amino esensial dalam jumlah yang adekuat untuk pertumbuhan bayi (Lonnerdal, 2003).

Di awal masa kehidupan bayi, imunoglobulin A sekretorik (sIgA) yang dihasilkan oleh mukosa usus bayi belum dapat berperan secara optimal didalam sistem pertahanan mukosa usus. Pada bayi yang menyusu, pertahanan imun pada jaringan usus bayi dibantu oleh komponen imun ASI. Salah satunya adalah antibodi IgA yang merupakan komponen imun utama, yang mengikat mikroba patogen, mencegah perlekatannya pada sel enterosit di usus dan mencegah reaksi imun yang bersifat inflamasi (Jackson \& Nazar , 2006; Hanson, 2007).

Kelenjar mammaria ibu merupakan bagian integral dari kelenjar getah bening mukosa. Bila pada masa laktasi terjadi stimulasi sel limfosit di dalam kelenjar getah bening mukosa jaringan usus halus dan saluran nafas ibu oleh suatu antigen, maka sel-sel limfosit yang telah tersensitisasi akan bermigrasi dan masuk ke dalam kelenjar mammaria. Selanjutnya berubah menjadi sel plasma yang dapat menghasilkan antibodi IgA yang disekresi ke dalam ASI. Antibodi IgA ASI akan memiliki sifat spesifik terhadap mikroba patogen yang menyerang usus halus bayi (Lawrence and Lawrence, 2011).

Penelitian Saleh, dkk (2009) di Kabupaten Maros Sulawesi Selatan memberikan hasilbahwa, adanya pengaruh yang efektif dari pendidikan kesehatan dengan pendekatanmodeling yang dilakukan oleh bidan terhadap peningkatan pengetahuan ibu,kemampuan dalam praktek menyusui dan kepercayaan diri ibu dalam memberikan ASIpada bayinya. Faktor lain yang berdistribusi terhadap pemberian ASI adalah keyakinandan motivasi terhadap pemberian ASI. Berdasarkan penelitian yang dilakukan oleh Man dan Chow pada (2010) di Hongkong, bahwa keyakinan dan motivasi ibu adalah faktoryang cukup berpengaruh dalam praktek pemberian ASI. Ibu yang mempunyai tingkatmotivasi dan keyakinan diri yang baik akan lebih mampu memberikan ASI, dibandingkanibu dengan motivasi dan keyakinan rendah. Tidak adanya pendampingan setelah melahirkan oleh petugas kesehatan juga menjadi faktor kegagalan pemberian ASI eksklusif, berdasarkan observasi petugas kesehatan baru mengetahui ibu tidak menyusui eksklusif pada saat mengimunisasikan bayinya. American Dietetic Association (2009), menyatakan bahwa dukungan yang berkelanjutan sangat penting untuk menjamin keberhasilan pemberian ASI.

Penelitian ini dilaksanakan untuk mengetahui pengaruh pendamping pemberian ASI terhadap kadar sekretori imunoglobulin A (sIg A) pada neonatus di Wilayah Kerja Puskesmas Rumbai Pekanbaru 2017.

\section{METODE PENELITIAN}

Jenis Penelitian ini merupakan suatu penelitian quasy eksperiment dengan disign Pretest dan Post-test Control Group. Desain penelitian ini terdiri dari dua kelompok, yaitu kelompok intervensi dan kelompok kontrol. Kelompok intervensi diberikan perlakuan sedangkan kelompok kontrol tidak diberikan perlakuan. Penelitiandilakukan pada 2 tempat yaitu: Wilayah Kerja Puskesmas Rumbai dan Laboratorium Biomedik Fakultas Kedokteran Universitas Andalas untuk pemeriksaan sIgA feses neonatu.Waktu Penelitian dilaksanakan dari bulan 
Januari hingga Nopember 2017. Populasi penelitian ini adalah semua neonatus yang berumur 0-28 hari di Wilayah Kerja Puskesmas RumbaiPekanbaru 2017.Besar sampel dalam penelitian ini peneliti membatasi besar sampel 30 orang, yaitu neonatus normal 0-28 hari yang dilahirkan melalui proses persalinan normal yang berjumlah 15 orang sebagai kelompok yang dilakukan pendampingan pemberian ASI dan yang tidak dilakukan pendampingan pemberian ASI berjumlah 15 orang.Pengolahan data dilakukan secara komputerisasi dengan analisa datamelakukan analisis univariat, uji normalitas data, dan analisisbivariat. Uji normalitasdata pada penelitian ini menggunakan uji Shapiro-Wilk karena sampel $\leq 50$. AnalisisBivariat pada penelitian ini menggunakan uji $T$ dependen untuk mengetahui perbedaan kadar sIg A sebelum dan setelah pada neonatus yang tidak dilakukan pendampingan pemberian ASI karenadata berdistribusi normal, sedangkan perbedaan kadar sIg A sebelum dan setelah pada neonatus yang dilakukan pendampingan pemberian ASI diuji dengan uji Wilcoxon karena data tidak berdisribusi normal. Untuk mengetahui pengaruh pendampingan pemberian ASI terhadap kadar sIg A pada neonatus yang dilakukan pendampingan dan yang tidak dilakukan pendampingan pemberian ASI dengan menggunakan uji $\mathrm{T}$ independen.

\section{HASIL PENELITIAN}

Tabel 1

Perbedaan Kadar sIg A Sebelum dan Setelah pada Neonatus yang Tidak Dilakukan Pendampingan Pemberian ASI

\begin{tabular}{|c|c|c|c|c|c|}
\hline No. & Variabel & $\mathrm{n}$ & Mean & SD & p \\
\hline \multirow{4}{*}{1.} & Kadar sIgA & & & & \multirow{6}{*}{0,000} \\
\hline & Sebelum & 1 & 133,03 & 19,74 & \\
\hline & (hari ke-1) & 5 & 4 & & \\
\hline & $\mu \mathrm{g} / \mathrm{ml}$ & & & & \\
\hline \multirow{2}{*}{2.} & Kadar & 1 & 68,2 & 33,3 & \\
\hline & SigA & 5 & 47 & 74 & \\
\hline
\end{tabular}

(hari ke-

28) $\mu \mathrm{g} / \mathrm{ml}$

Tabel 2

Perbedaan Kadar sIg A Sebelum dan Setelah pada Neonatus

yang Dilakukan Pendampingan Pemberian ASI

\begin{tabular}{|c|c|c|c|c|c|}
\hline $\begin{array}{l}\mathbf{N} \\
\mathbf{0 .}\end{array}$ & Variabel & n & Median & $\begin{array}{l}\text { Minimu } \\
\text { m- } \\
\text { Maksim } \\
\text { um } \\
\end{array}$ & $\mathbf{p}$ \\
\hline 1. & $\begin{array}{l}\text { Kadar sIgA } \\
\text { Sebelum (hari ke- } \\
\text { 1) } \mu \mathrm{g} / \mathrm{ml}\end{array}$ & $\begin{array}{l}1 \\
5\end{array}$ & 142,999 & $\begin{array}{l}73,086- \\
162,286\end{array}$ & \multirow{2}{*}{0,004} \\
\hline 2. & $\begin{array}{l}\text { Kadar sIgA } \\
\text { Sesudah (hari ke- } \\
\text { 28) } \mu \mathrm{g} / \mathrm{ml}\end{array}$ & $\begin{array}{l}1 \\
5\end{array}$ & 37,996 & $\begin{array}{c}6,387- \\
224,163\end{array}$ & \\
\hline
\end{tabular}

Tabel 3

Perbedaan Kadar sIg A pada Neonatus yang Tidak Dilakukan Pendampingan dan Dilakukan Pendampingan Pemberian ASI

\begin{tabular}{|c|c|c|c|c|c|c|}
\hline No & Variabel & $\mathrm{n}$ & Mean & SD & SE & $\mathbf{p}$ \\
\hline 1 & $\begin{array}{l}\text { Kada sIg A } \\
\text { pada neonatus } \\
\text { yang tidak } \\
\text { dilakukan } \\
\text { pendamping } \\
\text { pemberian ASI } \\
(\mu \mathrm{g} / \mathrm{ml})\end{array}$ & 26 & 6,825 & 33,374 & 8,617 & \multirow{2}{*}{0,624} \\
\hline 2 & $\begin{array}{l}\text { Kada sIg A } \\
\text { pada neonatus } \\
\text { yang tidak } \\
\text { dilakukan } \\
\text { pendamping } \\
\text { pemberian ASI } \\
(\mu \mathrm{g} / \mathrm{ml})\end{array}$ & 26 & 5,933 & 61,259 & 15,782 & \\
\hline
\end{tabular}

\section{PEMBAHASAN}

Penelitian di lakukan di wilayah kerja puskesmas Rumbai Pekanbaru dan Laboratorium Biomedik Fakultas Kedokteran Universitas Andalas dengan jumlah responden 15 orang yang tidak dilakukan pendampingan pemberian ASI dan 15 orang yang dilakukan pendampingan pemberian ASI. Berdasarkan hasil penelitian yang telah didapat maka peneliti membahas secara sistematis hasil analisis data penelitian. Pada data yang tidak dilakukan pendampingan pemberian ASI diketahui data berdistribusi normal setelah dilakukan uji normalitas, sedangkan pada data yang dilakukan pendampingan 
pemberian ASI data tidak berdistribusi normal setelah dilakukan uji normalitas. Namun ketika dilakukan transformasi sebanyak 3 kali, pada data pre atau sebelum dilakukan pendampingan pemberian ASI didapatkan data tidak berdistribusi normal dan post atau setelah didapatkan data berdistribusi normal.

$$
\text { Pada data yang dilakukan }
$$

pendampingan pemberian ASI selanjutknya dilakukan uji wilcoxon untuk mengetahui kadar sIg A sebelum dan setelah dilakukan pendampingan dan pada data yang tidak dilakukan pendampingan pemberian ASI selanjutnya dilakukan uji t-dependen untuk mengetahui kadar sIg A sebelum dan setelah tidak dilakukan pendampingan.

Berdasarkan hasil uji statistikdari 15 responden yang tidak dilakukan pendampingan pemberian ASI menunjukkan bahwa mean pada hari ke-1 lebih tinggi daripada hari ke-28 yaitu hari ke-1 sebesar 133.03460 dan hari ke-28 sebesar 68.24667.Terlihat bahwa terjadi penurunan kadar sIg A pada hari ke-28 sebesar 6.478.793. Sementara itu dari 15 responden yang dilakukan pendampingan pemberian ASI menunjukkan bahwa mean pada hari ke-1 lebih tinggi daripada hari ke-28 yaitu hari ke-1 sebesar133.19527danhari ke-28 sebesar 59.33567.Terlihat bahwa terjadi penurunan kadar sIg A pada hari ke-28 sebesar 7.385.960. Dapat disimpulkan bahwa apabila penurunannya besar maka kandungan sIg A pada feses neonatus lebih sedikit. Namun dibandingkan dengan tidak dilakukan pendampingan pemberian ASI, penurunan sIg A pada hari ke-28 lebih besar pada neonatus yang dilakukan pendampingan pemberian ASI yang berarti kandungan sIg A pada feses neonatus tersebut lebih sedikit.

Neonatus yang menjadi sampel dalam penelitian ini sama-sama mendapat IMD. Berdasarkan teorinya IMD memungkinkan bayi mendapatkan kolostrum dan ASI ekslusif di kemudian hari (Suharyono, 1990). Sebagaimana yang diketahui bahwa kolostrum pada ASI memiliki banyak manfaat, salah satunya antibodi. Salah satu antibodi yang dimilikinya adalah Ig A.Imunoglobulin A ( $\operatorname{Ig} \mathrm{A})$ adalah antibodi yang berbentuk dimer tersimpan di dalam sel basal, diubah menjadi s-IgA melalui penambahan komponen sekretorik yang kemudian disekresi ke dalam lumen usus atau ke bagian apeks dari epitel mukosa usus. Ig A bermanfaat dalam melindungi infeksi saluran pernafasan, saluran usus lambung, dan mata (Sarwono, 2010). Oleh karena pada hari pertama atau minggu pertama kelahiran bayi mendapat kolostrum atau ASI yang memiliki zat kekebalan tubuh yang tinggi maka juga ditemukan kadar sIg A yang tinggi pada feses neonatus pada hari pertama lahir.

Selain itu berdasarkan teori, ketika baru lahir bayi belum mampu membuat kekebalan tubuh sendiri secara sempurna dan kelenjar timus yang berfungsi untuk mengontrol proses kekebalan tubuh juga masih berkembang. Oleh karena itu tingginya kadar sIg A yang ditemukan pada feses bayi bisa dikarenakan oleh kurangnya kemampuan bayi dalam mengabsorpsi atau menyimpan sIg A dari ASI. Namun dari hasil penelitian menunjukkan bahwa terjadi peningkatan kelenjar timus pada bayi yang diberikan ASI dibandingkan yang tidak mendapatkan ASI. Hal ini dapat disimpulkan bahwa bayi baru lahir tetap mendapat antibodi yang cukup apabila diberikan ASI meskipun sebagian antibodi tersebut bisa saja terbuang melalui feses karena kurangnya kemampuan bayi dalam menyimpan antibodi pada hari-hari pertama setelah lahir.

Dibandingkan penurunan kadar sIg A sebelum dan setelah pada responden yang tidak dilakukan pendampingan pemberian ASI dan yang dilakukan pendampingan pemberian ASI, maka penurunan kadar sIg A pada responden yang dilakukan pendampingan 
pemberian ASI lebih tinggi daripada yang tidak dilakukan pendampingan. Artinya ditemukan sedikit sIg A pada feses neonatus yang mendapat pendampingan pemberian ASI. Hal ini dapat disimpulkan bahwa neonatus tersebut memiliki cukup kemampuan untuk mengabsorpsi atau menyimpan antibodi dari ASI sehingga tidak terbuang melalui feses. Hal ini sejalan juga bisa dikarenakan dengan adanya pendampingan ibu akan termotivasi memberikan ASI pada bayinya sehingga dari segi frekuensi dan kandungan gizi atau volume ASI yang diberikan juga berbeda pada neonatus yang mendapat pendampingan dengan yang tidak pendampingan.

Selain hal diatas penurunan kadar sIg A pada feses neonatus bisa juga dikarenakan oleh menurunnya antibodi yang diterima bayi dari ASI ibu. Dan bisa juga dikarenakan kemampuan bayi yang sudah berkembang dalam menyimpan antibodi sehingga tidak banyak antibodi yang terbuang melalui feses.

Berdasarkan hasil uji tindependen didapatkan hasil bahwa tidak ada perbedaan yang signifikan kadar sIg A antara neonatus yang dilakukan pendampingan pemberian ASI dan yang tidak dilakukan pendampingan pemberian ASI. Namun dari mean atau rata-rata kadar sIg A pada neonatus yang tidak dilakukan pendampingan pemberian ASI lebih tinggi daripada neonatus yang dilakukan pendampingan pemberian ASI. Walaupun selisihnya tidak jauh berbeda. Hal ini bisa saja karena bukan dari frekuensi dari pendampingan itu sendiri, tapi dari frekuensi pemberian ASI dan emosional serta tingkat gizi dalam ASI yang didapat dari asupan ibu. Ini tentu tidak terlepas dari pendampingan, terutama pendampingan yang membuat ibu nyaman. Sebagaimana menurut teori Model Ramona T. Mercer bahwa dukungan pada ibu seperti dalam bentuk pendampingan akan meningkatkan kondisi psikologis dan peran ibu dalam bentuk kepercayaan diri. Kepercayaan ibu akan meningkatkan peran ibu dalam melakukan perawatan dan pemberian ASI pada bayinya (Mercer and Walker, 2006).

Pada penelitian ini responden yang dipilih sama-sama mendapatkan IMD, baik yang tidak mendapat pendampingan maupun yang mendapat pendampingan pemberian ASI. Hal ini yang mungkin menyebabkan tidak adanya perbedaan yang signifikan kadar sIg A pada neonatus yang tidak dilakukan pendampingan pemberian ASI dengan yang dilakukan pendampingan pemberian ASI.

\section{KESIMPULAN}

1. Terdapat perbedaan kadar sIg A sebelum dan sesudah pada neonatus yang tidak dilakukan pendampingan pemberian ASI.

2. Terdapat perbedaan kadar sIg A sebelum dan sesudah pada neonatus yang dilakukan pendampingan pemberian ASI.

3. Tidak terdapat perbedaan kadar sIg A pada neonatus yang dilakukan pendampingan dan tidak dilakukan pendampingan pemberian ASI.

\section{SARAN}

\section{Bagi Akademik}

Dalam upaya promotif institusi pendidikan dapat membuat bahan ajar tentang penting pendampingan pemberian ASI agar dapat memotivasi ibu dalam memberikan ASI pada bayinya dengan frekuensi dan kualitas ASI yang baik.

\section{Bagi Terapan}

Bagi para bidan dapat memberikan pendidikan kesehatan kepada masyarakat khususnya ibu menyusui agar memberikan ASI ekslusif kepada bayinya karena pemberian ASI ekslusif sangat berperan dalam menurunkan risiko terjadinya penyakit diare pada bayi yang disebabkan oleh infeksi serta tetap melakukan 
pendampingan pemberian ASI pada ibu menyusui, terutama pendampingan dari keluarga.

\section{Bagi Pengembangan Penelitian}

Penelitian selanjutnya dapat meneliti variabel yang berbeda seperti Imunoglobin $\mathrm{G}$ (Ig $\mathrm{G}$ ) dan pemeriksaan laboratorium yang berbeda seperti dari serum atau saliva.

\section{DAFTAR PUSTAKA}

American Academy of Pediatrics Section on Breastfeeding, 2005. Breastfeeding and The Use of Human Milk. American Academy of Pediatrics.

Atikah dan Eni, 2010. Kapita Selekta: ASI \& menyusui. Penerbit Nuha Medika, Yogyakarta.

Atiqa, UD. 2016. Perbedaan Pertumbuhan dan Perkembangan Bayi Usia 6 Bulan Yang Diberikan ASI Eksklusif dan Non Eksklusif di Wilayah Kerja Puskesmas Kelurahan Tamalarea Makassar. Skripsi Program Studi Fisioterapi Fakultas Kedokteran Universitas Hasanuddin Makassar.

Ballard O, Morrow AL, 2013. Human Milk Composition: Nutrients and Bioctive Factors.Pediatr Clin North Am, 60(1), 1-24. http://doi.org/10.1016/j.pcl.2012.1 0.002.Human.

Dahlan MS, 2011. Statistik Untuk Kedokteran dan Kesehatan Edisi 5. Jakarta, Salemba Medika.

Dahlan MS, 2014. Langkah - Langkah Membuat Proposal Penelitian Bidang Kedokteran dan Kesehatan. Seri Evidence Based Medicine. Ed. 2 Cetakan 3.

Gross SM, Resnik AK, Nanda JP, CrossBarnet C, Augustyn M, Kelly L, Paige DM, 2011. Early Postpartum: A Critical Period in Setting the Path for Breastfeeding
Success. Breastfeeding Medicine, 6(6), 407-412. http://doi.org/10.1089/bfm.2010.0 089.

Hanson LA. Symposium on 'Nutrition in early life: new horizon in a new century'. Sesion 1: Feeding and infant development, Breastfeeding and immune function. Proceeding of the Nutrition Society 2007; 66: 384-396.

Heymann J, Earle A, 2013. Breastfeeding policy: a globally comparative analysis, (April), 398-406.

Hidayat, A. A. (2012). Pengantar Ilmu Keperawatan Anak. Jakarta: Salemba Medika.

Jackson KM and Naza AM. Breastfeeding, the immune response, and long - term health. J. Am Osteopath Assoc, 2006 ; $106: 203-207$.

Kaetzel CS, Robinson JK, Chintalacharuna KR, dkk. The Polymeric Immnunoglobulin Receptor (Secretory Component) Mediates Transport of Immunoe Complexcs Across Epithelial Cells : A Local Defense Function for IgA. Proc. Natl. Acad. Sci USA, 1991, $88: 8796-8800$.

Kementerian Kesehatan Republik Indonesia (Kemenkes RI), 2013. Pekan ASI Sedunia 2013. Breastfeeding Support. Akses 11 Oktober 2015. http://www.gizikita.depkes.go.id/ pekan-ASI-sedunia-2013/.

Lawrence RM, Lawrence RA, 2011. Breastfeeding. A Guide For The Medical Profession. $7^{\text {th }}$ Ed. Saunders Elsevier.

Maryunani , A. 2009. Asuhan Pada Ibu Nifas. Cetakan I. TIM. Jakarta.

Man-Ku, C., \& Chow, S.K.Y. (2010). Factors influencing the practice of exclusive breastfeeding among Hongkong Chinese women: A questionnaire survey. Journal of Clinical Nursing, 19, 2434-2445. 
Morrow AL dan Rangel JM. Human milk protection against infectious diarrhea: implications for prevention and clinical care. Semin Pediatr Infect Dis 2004; 15: 221-228.

Ms K, Kakuma R, Kramer MS, Kakuma $\mathrm{R}$, 2012. Optimal duration of exclusive breastfeeding (Review) Optimal duration of exclusive breastfeeding. Biostatistics,(8). http://doi.org/10.1002/14651858. CD003517.pub2.Copyright.

Newton ER, 2005. Lactation and Breastfeeding. Obstetrics: Normal and Problem Pregnancies (Sixth Edit). Elsevier Inc. http://doi.org/10.1016/B978-14377-1935-2.00023-5.

Nurheti, Yuliarti. 2010. Keajaiban ASIMakanan Terbaik untuk Kesehatan, Kecerdasan, dan Kelincahan Si Kecil. Yogyakarta: CV Andi.

Riset Kesehatan Dasar (Riskesdas), 2013. Badan Penelitian dan Pengembangan Kesehatan Kementerian Kesehatan RI Tahun 2013.

Saleha, Sitti. (2009). Asuhan Kebidanan pada Masa Nifas. Jakarta: Salemba Medika.

Saleh, A., Nurachmah, E., As'ad, S., \& Hadju, V. (2009). Pengaruh pendidikan kesehatan dengan pendekatan modelling terhadap pengetahuan, kemampuan praktek dan percaya diri ibu dalam menstimulasi tumbuh kembang bayi 0-6 bulan di Kabupaten Maros. 19 Febuari 2012. pasca.unhas.ac.id/jurnal/4dfd694e 7da095c426fa76ffbdf2b3ea.pdf 